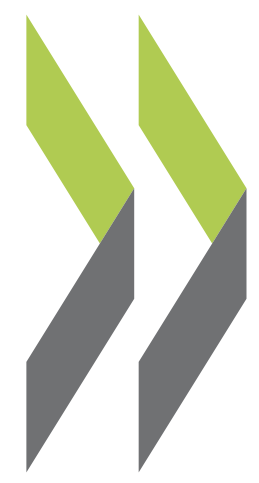

OECD Economics Department Working Papers No. 1243

Restoring the financial sector and corporate Urban Sila deleveraging in Slovenia 


\section{Unclassified}

ECO/WKP(2015)61

Organisation de Coopération et de Développement Économiques

Organisation for Economic Co-operation and Development

25-Jun-2015

ECONOMICS DEPARTMENT

English - Or. English

RESTORING THE FINANCIAL SECTOR AND CORPORATE DELEVERAGING IN SLOVENIA

ECONOMICS DEPARTMENT WORKING PAPERS No. 1243

By Urban Sila

OECD Working Papers should not be reported as representing the official views of the OECD or of its member countries. The opinions expressed and arguments employed are those of the author(s).

Authorised for publication by Alvaro Pereira, Director, Country Studies Branch, Economics Department.

All Economics Department Working Papers are available at www.oecd.org/eco/workingpapers

JT03379442

Complete document available on OLIS in its original format

This document and any map included herein are without prejudice to the status of or sovereignty over any territory, to the delimitation of international frontiers and boundaries and to the name of any territory, city or area. 
OECD Working Papers should not be reported as representing the official views of the OECD or of its member countries. The opinions expressed and arguments employed are those of the author(s).

Working Papers describe preliminary results or research in progress by the author(s) and are published to stimulate discussion on a broad range of issues on which the OECD works.

Comments on Working Papers are welcomed, and may be sent to the Economics Department, OECD, 2 rue André-Pascal, 75775 Paris Cedex 16, France, or by e-mail to eco.contact@oecd.org. .

The statistical data for Israel are supplied by and under the responsibility of the relevant Israeli authorities. The use of such data by the OECD is without prejudice to the status of the Golan Heights, East Jerusalem and Israeli settlements in the West Bank under the terms of international law.

\section{(C) OECD (2015)}

You can copy, download or print OECD content for your own use, and you can include excerpts from OECD publications, databases and multimedia products in your own documents, presentations, blogs, websites and teaching materials, provided that suitable acknowledgment of OECD as source and copyright owner is given. All requests for commercial use and translation rights should be submitted to rights@oecd.org 
ECO/WKP(2015)61

\section{ABSTRACT/RÉSUMÉ \\ Restoring the financial sector and corporate deleveraging in Slovenia}

Excessive credit growth, poor risk assessment and lax lending standards in the run up to the 2008 global crisis led to unsustainable debt build-up in banks and related corporates. A weak framework for the governance of largely state-owned banks is likely to have contributed to the misallocation of credit. Furthermore, there were weaknesses in the banks' risk management systems and banks often didn't properly adhere to regulations and guidance given by the supervisor. Following the results of the stress tests and the Asset Quality Review, in December 2013, the major state-owned banks were recapitalised at a cost of around 11\% of GDP, and part of their non-performing loans (NPLs) transferred to the Bank Asset Management Company (BAMC). Banks nevertheless remain weak, with still high NPLs, and corporations are highly leveraged. For successful restructuring and liquidation of assets, BAMC needs to act independently, transparently, with corporate governance of highest standards. Privatisation can improve corporate governance and closer supervision can ensure better compliance by banks. Insolvency legislation was thoroughly reformed in 2013 and should be implemented effectively to help return the healthy parts of the economy to invest and grow again.

This Working Paper relates to the 2015 OECD Economic Survey of Slovenia (www.oecd.org/eco/surveys/economic-survey-slovenia.htm).

JEL classification: G2, G3

Keywords: Slovenia, banking system, insolvency framework, deleveraging, corporate debt

\section{Restaurer le secteur financier et le désendettement des entreprises en Slovénie}

Une croissance excessive du crédit, une mauvaise évaluation des risques et des normes de crédit laxistes pendant la crise mondiale de 2008 ont conduit à un endettement insoutenable dans les banques et les entreprises connexes. Une faible gouvernance des banques quasi-nationalisées a contribué à la mauvaise allocation du crédit. En outre, il y avait des faiblesses chez les banques dans les systèmes de gestion des risques, ils n'étaient pas souvent en conformité avec la réglementation et les directives données par le superviseur. Suite aux résultats des tests de résistance et l'examen de la qualité des actifs, en Décembre 2013, les grandes banques appartenant à l'État ont été recapitalisées à un coût d'environ $11 \%$ du PIB, et une partie de leurs prêts non performants (PNP) transférés à la Banque Asset Management Company (BAMC). Les banques restent néanmoins faibles, avec des créances improductives élevées, et les entreprises sont fortement endettées. À fin de réaliser une restructuration et une liquidation des actifs, BAMC doit agir de façon indépendante et transparente, avec une gouvernance des normes d'entreprise plus important. La privatisation peut améliorer la gouvernance d'entreprise et une surveillance plus étroite peut assurer un meilleur respect par les banques. La législation de l'insolvabilité a été réformée en profondeur en 2013 et devrait être mise en œuvre pour aider à retrouver les parties saines de l'économie à investir et crôitre à nouveau. .

Ce Document de travail se rapporte à l'Étude économique de l'OCDE de la Slovénie, 2015 (www.oecd.org/fr/eco/etudes/etude-economique-slovenie.htm).

Classification JEL: G2, G3

Mots clefs: La Slovénie, le système bancaire, l'insolvabilité cadre, le désendettement, la dette d'entreprise 


\section{TABLE OF CONTENTS}

\section{RESTORING THE FINANCIAL SECTOR AND CORPORATE DELEVERAGING IN SLOVENIA.......5}

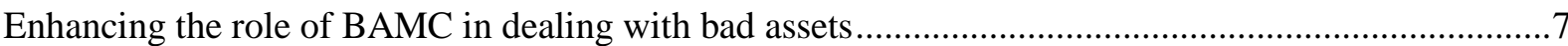

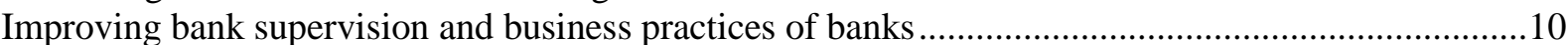

Improved insolvency framework to speed up corporate restructuring .............................................11

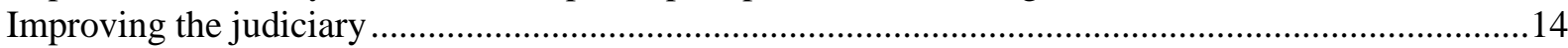

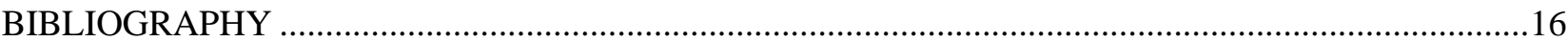

\section{Figures}

3.1 The banking sector was hit hard by the boom-bust credit cycle, but restructuring

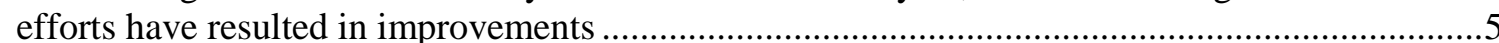

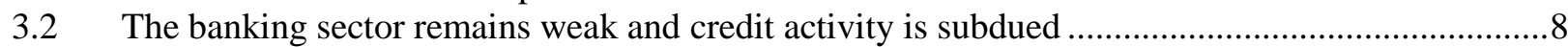

3.3 The debt overhang is concentrated in a few companies.........................................................11

3.4 Deleveraging has been under way, while corporates still face elevated funding costs ..................12 
ECO/WKP(2015)61

\title{
RESTORING THE FINANCIAL SECTOR AND CORPORATE DELEVERAGING IN SLOVENIA
}

\author{
By Urban Sila ${ }^{1}$
}

1. The banking sector was hit hard by the boom-bust credit cycle. A combination of low interest rates, overly optimistic growth expectations and a massive inflow of foreign wholesale funding raised the loan-to-deposit ratio to $160 \%$ in 2008 (Figure 1, panel A). The credit-to-GDP ratio more than doubled between 2003 and 2011 to 58\% of GDP, although it remained below the levels seen in Ireland, for example. The loans were mainly directed to the corporate sector as household indebtedness remained low. The unwinding of the lending boom and the large drop in economic activity increased non-performing loans (NPLs) to 18\% of total loans at the end of 2013 (Figure 1, panel B), mostly in the large state-controlled banks. The deterioration in asset quality left Slovenian banks poorly capitalized and ill-equipped to extend further credit to the private sector, holding back investment and consumption (Figure 1, panels C and D).

\section{Figure 1 The banking sector was hit hard by the boom-bust credit cycle, but restructuring efforts have} resulted in improvements

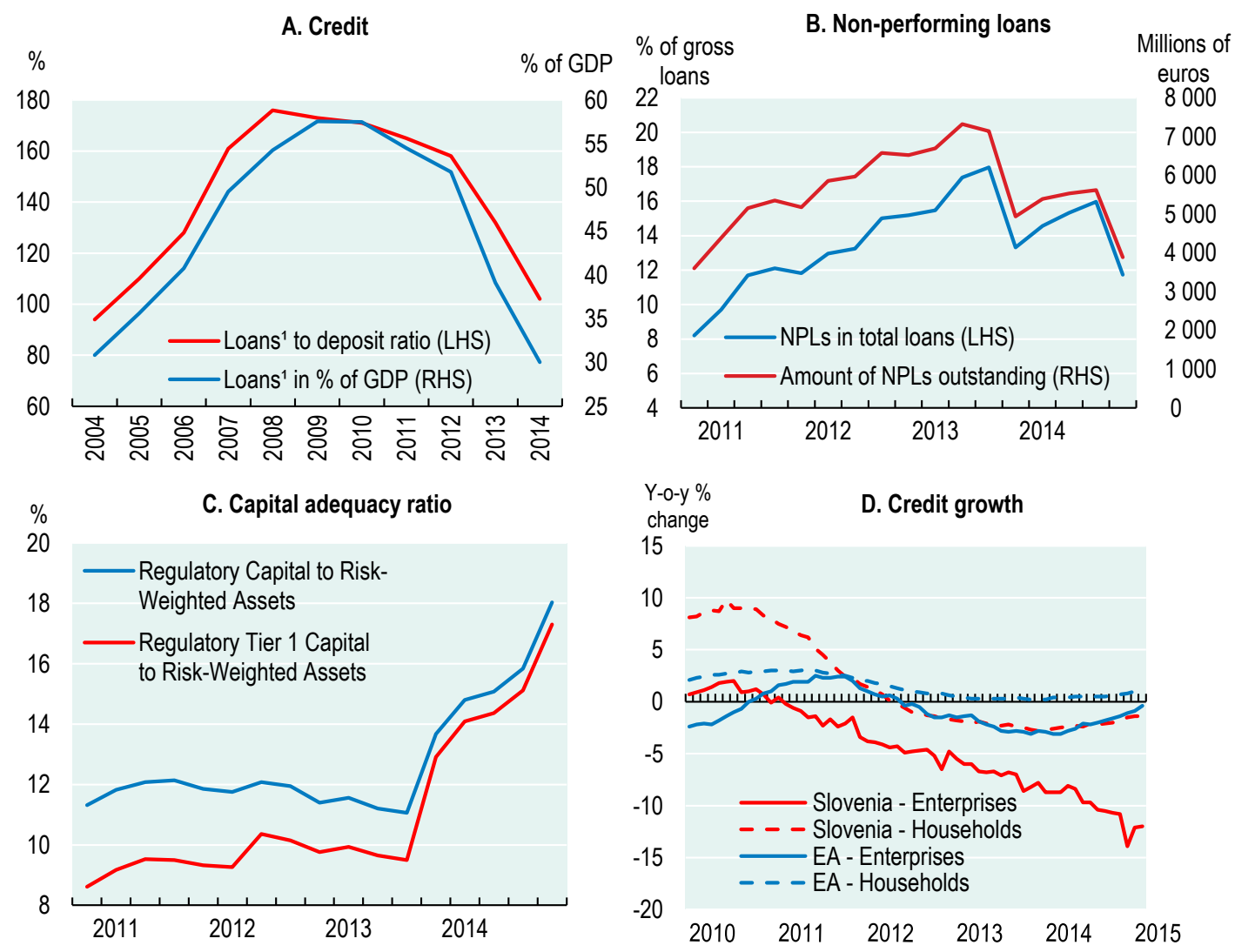

1. Outstanding amount at the end of the period.

Source: ECB Statistical Data Warehouse, for Panels A and D; and IMF Financial Soundness Indicator database for Panels B and C.

\footnotetext{
${ }^{1}$ Urban Sila is an Economist working in the Economics Department, on the Slovenia desk. This paper is extracted from Chapter 3 of the 2015 OECD Economic Survey of Slovenia, published in May 2015 under the authority of the Economic and Development Review Committee (EDRC). The author especially thanks Piritta Sorsa, Nataša Jemec, Robert Ford, Álvaro Pereira, Slovenian government officials, and officials from the Bank of Slovenia for valuable comments on earlier drafts, Hermes Morgavi for statistical support and Anthony Bolton for editorial assistance.
} 
2. In late 2012 the authorities became more resolute about restructuring the increasingly troubled state-owned banking sector as the related uncertainty led to a sharp rise in sovereign spreads and funding difficulties. Previous attempts, over 2011 and 2012, to boost capital of the large state banks by EUR 0.7 billion had failed to make them viable. In December 2012 the parliament adopted amendments to the Banking Act entrusting Bank of Slovenia with additional resolution powers, and the Act Defining the Measures of the Republic of Slovenia to Strengthen Bank Stability that, among others, established conditions for setting up a Bank Asset Management Company (BAMC). In addition, in September 2013, Bank of Slovenia announced a supervised winding down of two small private banks, together accounting for $4.5 \%$ of total assets (IMF, 2014), that had been facing recurrent losses and failed to raise adequate capital.

3. BAMC was established to have a key role in managing, liquidating and restructuring bad assets. In March 2013, BAMC was incorporated as a state owned company with the principal goal of recovering the highest possible value for the transferred assets, thereby minimising the cost to the budget of banking sector restructuring (BAMC, 2014). By law, BAMC can issue up to EUR 4 billion of governmentguaranteed bonds (about 11\% of GDP) to acquire the impaired assets of banks. BAMC has the legal instruments and the power to seek quick resolution of impaired assets, for example, by restructuring the company when it holds more than $50 \%$ of claims. Bankruptcy procedures where BAMC is involved are to be concluded within six months. BAMC can acquire additional assets from other banks to facilitate corporate restructuring, but has to purchase them at market prices. The law stipulates the life-span of the BAMC at five years - until the end of 2017 - after which the remaining assets are to be transferred to the Slovenia Sovereign Holding (SSH) (BAMC, 2014; IMF, 2014).

4. The asset transfers and bank restructuring were complicated and delayed due to pricing concerns. Any transfer of assets from banks to asset management companies comes under the scrutiny of European Commission Directorate General for Competition (DG Comp). The transfers need to abide by the EC rules for state aid to avoid using public funds to compensate private losses. Fair pricing based on credibly estimated market value is important on one hand for banks to appropriately recognise the past losses, and on the other hand to offer a restructuring vehicle (BAMC in this case) an opportunity to make profit. Given rising uncertainties and the seeming unwillingness of the authorities and banks to fully recognise the size of the losses, the European Commission and the ECB insisted that Slovenia perform a comprehensive Stress tests and Asset Quality Review (AQR) of 8 Slovenian banks, undertaken by independent experts.

5. The announcement of the results of the stress tests, in December 2013, gave an important push to bank resolution. Under the adverse scenario, total capital needs of the banks stood at EUR 4.8 billion (about 13\% of GDP) (Bank of Slovenia, 2013). The European Commission approved new recapitalisations for the two largest state-owned banks (NLB, NKBM) (European Commission, 2013). The European Commission also temporarily approved the rescue aid for Abanka (the third-largest state-owned bank) and authorities recapitalised the two small private banks undergoing resolution. The Bank of Slovenia also identified a group of banks that were given some time to boost their capital on the market. If unsuccessful the authorities promised to chip in. The authorities furthermore committed to fully privatise NKBM and Abanka, and to reduce the state ownership in NLB to $25 \%$ plus one share in the medium term. The capital of the BAMC was increased to ensure its smooth operations. The exercise, despite costly for the budget, significantly reduced uncertainty and calmed the financial markets. The sovereign bond yields that had been edging up to $7 \%$ over the summer and autumn of 2013, dropped below 5\% soon after the announcement of the results, and subsided further ever since. 
6. In 2014 measures to stabilise the banking sector continued. After the European Commission confirmed the restructuring plan for Abanka it was capitalised for another EUR 243 million in October, as initially planned. In October 2014, the authorities received two binding offers for NKBM, and the bank was expected to be sold in the first quarter of 2015, but there are delays. The winding-down of the two smaller domestic banks could be finalised ahead of time, with the full repayment of deposits and the return of the banking licences still in 2015. A smaller bank Banka Celje was recapitalised in December 2014 at a cost of EUR 190 million, and is eventually to be merged with Abanka. Since December 2013, the state has provided close to EUR 4 billion of capital to banks in total (11\% of GDP).

7. The physical transfers of the loan files to the BAMC from NLB and NKBM have been completed while the Abanka transfer was finalised in the first half of 2015. In total, the three large state-owned banks and another small bank are transferring EUR 4.86 billion in assets to the BAMC, at the transfer value of EUR 1.56 billion, or with a $68 \%$ average haircut BAMC has acquired additional corporate exposures at market prices from two smaller domestic banks in wind-down and further transfers from Banka Celje (European Commission, 2014a). Only about half of corporate NPLs have been transferred to the BAMC (IMF, 2015a), so there is room for further transfers. Foreign NPLs - consisting of lending to companies and subsidiaries of domestic banks in the Balkans - have not been transferred to the BAMC and constitute close to one quarter of total remaining NPLs (European Commission, 2015).

8. Restructuring has stabilised the banking sector, but there are still weaknesses. Despite the transfers of impaired assets to the BAMC, the level of non-performing loans on banks' balance sheets remains elevated (Figure 2, panel A). The level of provisioning however is higher than before and NPLs pose a lower risk to the solvency of banks (European Commission, 2015). The recapitalisations boosted capital, but capital ratios are not high compared to banks in other euro area countries (Figure 2, panel B). The results of the ECB's Comprehensive Assessment of European banks' balance sheets, announced in October 2014, showed a small capital shortfall under the adverse scenario for NLB and NKBM, amounting to less than $0.2 \%$ of GDP. But the report (ECB, 2014) states that the banks will not require additional recapitalisation, as after the restructuring efforts so far, both banks returned to profit, and they will be able to cover the capital shortfalls from retained earnings. Yet, profitability remains low and credit activity to the corporate sector is still declining (Figure 2, panels $\mathrm{C}$ and D). To return the banking sector to health in a sustainable manner, a stronger and better coordinated policy action is needed.

\section{Enhancing the role of BAMC in dealing with bad assets}

9. BAMC was established to recover bad assets, while the remaining cleaned-up banks could focus on normal banking operations. As reported in the 2013 Economic Survey, banks were initially unable or unwilling to deal with their bad loans. The average monthly ratio of written-off loans to overdue loans was only $0.2 \%$ in the first nine months of 2012 , so banks would require 40 years to clean up their loan portfolios (OECD, 2013a). Similarly, the BAMC in its 2013 Annual Report notes that the transfer prices for NPLs calculated and suggested by the banks themselves in spring 2013 were substantially overvalued.

10. A separate asset management company (AMC) to tackle bad assets allows banks to focus on core business while the AMC concentrates on asset recovery. A separate agency can exploit economies of scale in consolidating scarce skills and resources, and has enhanced bargaining power versus debtors. The disadvantage of taking assets away from banks is some loss of institutional knowledge about borrowers. Another disadvantage is that banks can provide additional financing, which can be important for restructuring (Klingebiel, 2000; Woo, 2000). For AMCs to successfully and effectively do their task, it is important that a country has an effective legal system and adequate insolvency regulation, and sound financial regulatory and supervisory framework. Professional management, political independence, a skilled resource base, appropriate funding, good information and management, and transparency in operations and processes are also key (Klingebiel, 2000; Woo, 2000). Finally, a stable macroeconomic environment can restore the viability of some nonperforming assets. 
Figure 2 The banking sector remains weak and credit activity is subdued

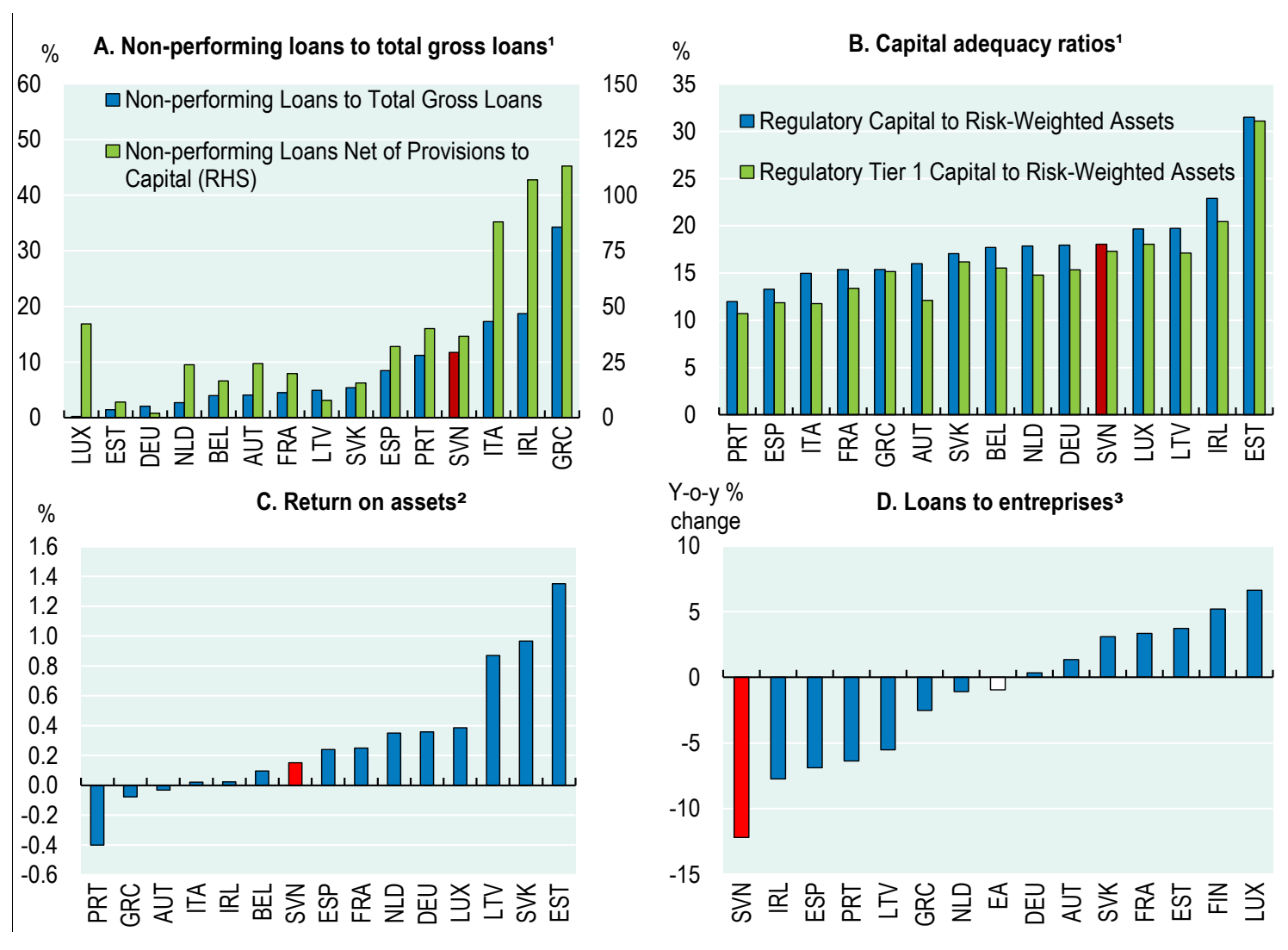

1. 2014 Q4 or latest data available.

2. Average return on assets in the four quarters of 2014, except for France and Germany whose data refers to 2013.

3. Average of annual growth rates between November 2014 and February 2015. Loans adjusted for sales and securitisation of all types of maturity.

Source: IMF Financial Soundness Indicator database, for Panels A, B and C; and ECB Statistical Data Warehouse, for Panel D.

11. Klingebiel (2000) reviews experience of seven countries (Ghana, Finland, Mexico, Spain, Sweden, the Philippines and the USA) that established AMCs to address the overhang of bad debt in the economy, and concludes that they have a mixed record. Laeven and Valencia (2008) find that AMCs have been set up in $60 \%$ of crises, but similarly report that they appear largely ineffective in resolving distressed assets. In practice, selling off assets of unviable bankrupt institutions had a higher rate of success than corporate restructuring. Moreover, when the assets acquired were mostly real estate related, the process was more successful. When AMCs only had a small fraction of the banking system on their balance sheets, it was easier to maintain its independence from political pressures (Klingebiel, 2000).

12. In the case of Slovenia, about two thirds of the BAMC's exposures are in default. BAMC is to acquire the collateral - mostly real estate but also equity and company assets - and sell it to the private sector. The other exposure is corporate assets that have a viable core activity but need to be financially and operationally restructured (European Commission, 2014a). From experience of other countries, the task of corporate restructuring can be more challenging, and especially so in Slovenia where there are numerous complex, inter-connected group loans with several bilateral contracts and conflicting interests (Bank of Slovenia, 2014). To speed up the process, policy makers should create an environment where the BAMC can successfully take a lead with its strong expertise. 
13. To do this, more assets should be transferred from banks to the BAMC. All assets in a company group should be transferred, so that the BAMC will have a majority position vis-à-vis other creditors. This will expedite the restructuring process and increase recovery prospects. Care should be taken, however, not to make the BAMC too big and thus susceptible to political influence. According to Klingebiel (2000), the successful cases of AMCs in Spain, Sweden and the USA each held assets below 10\% of total financial assets in the economy. This translates to the maximum size of BAMC of approximately EUR 6 billion, which is beyond the current limit of EUR 4 billion stipulated by law. BAMC in coordination with the authorities should decide strategically which are the most urgent and important cases in the economy to be restructured, and ensure that additional exposures are transferred. This will also alleviate the problem of NPLs on banks' balance sheets. But action needs to be taken swiftly. Past experience shows that ambiguity on what additional assets may or may not be eventually transferred to the AMCs limits banks' incentives to engage in corporate restructuring of assets remaining on their balance sheets (Klingebiel, 2000).

14. Independence and professionalism are also very important for success (Klingebiel, 2000). Restructuring companies requires specialised expertise which is highly valued on the market. BAMC therefore needs to have freedom to set its own remuneration policy to attract adequate talent. By Slovenian law, the BAMC is established as a company with a board of directors, a one-tier versus a two-tier (a supervisory board and a management board) governance structure. One-tier structure allows for greater influence of the single shareholder - the government - on operations. It is important to preserve adequate independence of the BAMC over its life span and the authorities should consider establishing a two-tier governance structure within the BAMC.

15. Extending the life-span of the BAMC would reduce pressure for fire sales and enhance its independence. The BAMC was created with a 5-year life. Due to past delays and to avoid any fire sales, this should be extended, but past experience shows that some time limit is good. AMCs are created to expedite restructuring and not delay it. There can be a tendency to prolong the process under unrealistic expectations of a turnaround in asset values. The authorities are planning to change legislation in order to extend the life of BAMC to 2022, which is a step in the right direction.

16. The governance of BAMC could be strengthened. The Slovenian Corruption Prevention Commission (CPC) and the Court of Audit in their reports voiced concerns about conflict of interest, significant corruption risks and irregularities in the BAMC with respect to hiring of external consultancies, remuneration policies, internal processes and corporate governance. The reports also urged the Ministry of Finance to ensure better supervision of the BAMC. Successful AMCs in the past have relied on a detailed set of directives and guidelines to its staff and contractors that covered a wide range of operations, including asset management and disposition, contract policies, bidding procedures and marketing. This minimized the possibility of fraud and made policy and cost evaluation more transparent and expedited the resolution process (Klingebiel, 2000). Steps should be taken to strengthen corporate governance of the BAMC, and to ensure that it adheres to highest standards. BAMC has taken measures to strengthen its own governance in 2014 by adopting strategic guidelines and a business strategy for asset management.

17. Successful restructuring and disposal of assets importantly rely on sound financial institutions and available markets to sell the assets. Deep and liquid capital markets help in this regard. However, in Slovenia fresh equity is scarce, BAMC cannot lend money to companies, while banks are weak and in the process of deleveraging. In fact, the authorities are planning to change the law to enable BAMC to lend to companies, which will facilitate restructuring. In addition, more openness to privatisation and foreign investors could therefore bring more fresh capital. Swift restructuring of the banking sector and resumption of credit activity is equally important. BAMC can use tools at its disposal to encourage banks to lend afresh to viable restructured companies, for example by putting up its collateral for fresh loans or assigning super-seniority status. Foreign funds specialising in turning around companies could enter the market to 
buy viable companies and/or inject fresh money into companies. There are special funds under the umbrella of the EBRD that specialise in this and could be used more.

\section{Improving bank supervision and business practices of banks}

18. The 2013 Economic Survey argued that the weak framework for the governance of state-owned banks is likely to have contributed to poor credit standards, excessive risk taking and misallocation of credit. The Slovenian Corruption Prevention Commission reported (CPC, 2013) that corrupt practices in allocation of credit had been wide spread in the state dominated banking system. Several chief executive officers cited political interference as one of the reasons for their decision to resign. The planned privatisations are welcome in this regard as they are expected to improve corporate governance. However, the decision to retain a blocking minority shareholding should be dropped. Especially if remaining shares are widely held, a controlling stake opens the door to political interference.

19. The risk management in banks should be of higher standard and bank supervisor should more closely monitor banks' adherence to regulations and guidance. The AQR from December 2013 identified several weaknesses in the banks' risk management systems (European Commission, 2014b). The data integrity validation highlighted deficiencies in IT systems and paper records, with significant gaps in several loan files. Most of the banks did not assign rating classes in line with the regulations issued by the Bank of Slovenia and in many instances the collateral valuations were out of date. The BAMC (2014) likewise notes that credit files received from the banks were in many cases incomplete and of poor quality. The risk management in banks should be of higher standard and bank supervisors should more closely follow that regulations and guidance are properly followed by the banks.

20. The ECB Single Supervisory Mechanism, in place from November 2014, will bring unified supervisory methodologies and standards at the Eurosystem level. New legislation was adopted in March 2015 in line with EU directives, to introduce capital shock absorbers, enhanced risk management and bank governance requirements, and improved transparency of bank operations through additional disclosure and assessment of systemic risks. Furthermore, a bank resolution fund has been established, to be financed by banks and managed by the central bank. To foster higher standards of the risk management and nonperforming exposures management in banks, the Bank of Slovenia has introduced number of measures, such as additional reporting of banks and requirements for individual plans for non-performing exposure management. As the absence of credit information sharing between banks is also likely to have contributed to poor risk outcomes (OECD, 2013a). According to the Bank of Slovenia, the Central Credit Registry is being upgraded to better support supervisory tasks (Bank of Slovenia, 2014a), which is welcome.

21. Recent macroprudential measures to address systemic risks are welcome. In 2014, the institutional framework for macroprudential oversight of the financial system was established by the Bank of Slovenia. The Financial Stability Committee sets recommendations to safeguard the stability of the financial system by early identification of systemic risks and takes preventive measures. The Bank of Slovenia has adopted two macroprudential instruments. The first places a cap on deposit interest rates and imposes a capital add-on requirement for exceeding this cap. This instrument mitigated income risk, by contributing to a reduction in passive interest rates, in the context of banks' competition for stable sources of funding. The second instrument limits the annual change in gross loan-to-deposit ratio (of the non-banking sector), in order to slow down the pressure on deleveraging in the banking sector. The aim is to encourage banks to moderate the contraction of lending to the non-banking sector (Bank of Slovenia, 2014b). 


\section{Improved insolvency framework to speed up corporate restructuring}

22. Corporate indebtedness is high (Figure 3, panel A), despite debt reduction since 2009 (Figure 4, panel A). Profitability is low due to high interest burden and the bank funding cost of Slovenian corporates remains elevated (Figure 4, panel B). The debt is concentrated in a few companies (Bank of Slovenia, 2014b; European Commission, 2014b; Damijan, 2014; IMAD, 2014a). Companies with financial debt exceeding EBITDA (earnings before interest, taxes, depreciation and amortisation) by a factor of five account for about $80 \%$ of financial debt, but represent only one third of companies (Figure 3, panel B). State-owned and state-controlled enterprises are also highly leveraged and continue to be at risk of default (European Commission, 2015). Many companies, however have been able to tap alternative sources of funding at lower cost. Slovenia therefore does have a healthy core of companies, often export-oriented, which did not over-borrow and even improved their business since the crisis (IMAD, 2014a). However, despite the concentration of excessive debt, the deleveraging has been shown to affect negatively the overall economy via lower activity and investment (IMAD, 2014b). Moreover, unlike in other vulnerable countries where the economic distress was concentrated in the real estate and construction sectors, in Slovenia the pattern is rather cross-sectorial, with many service sectors also affected (European Commission, 2014b).

23. European Commission (2014b) found that between 2007 and 2012, Slovenia's expenditures on state aid to the real economy more than tripled, to $1.3 \%$ of GDP. Yet, many of the companies that received aid still ended up in financial difficulties. Given the fiscal pressures, Slovenia needs to shift from subsidising troubled companies to providing a framework for swift liquidation of unviable companies and effective restructuring of viable ones. In addition, dynamic credit and equity markets that are able to support growth of healthy parts of the economy are needed. Attracting equity through privatisation and entry of foreign investors could enhance corporate deleveraging, while strengthening corporate governance. The authorities are already replacing subsidies by low cost loans to companies. Slovenia has taken measures to improve its framework for liquidation and restructuring of companies. Furthermore, in January 2015, the government appointed a task force for corporate restructuring and deleveraging, comprising government and central bank officials, tasked with monitoring and coordinating restructuring and deleveraging of companies, and proposing measures to make the processes more effective. However, further improvements could be made.

Figure 3 The debt overhang is concentrated in a few companies
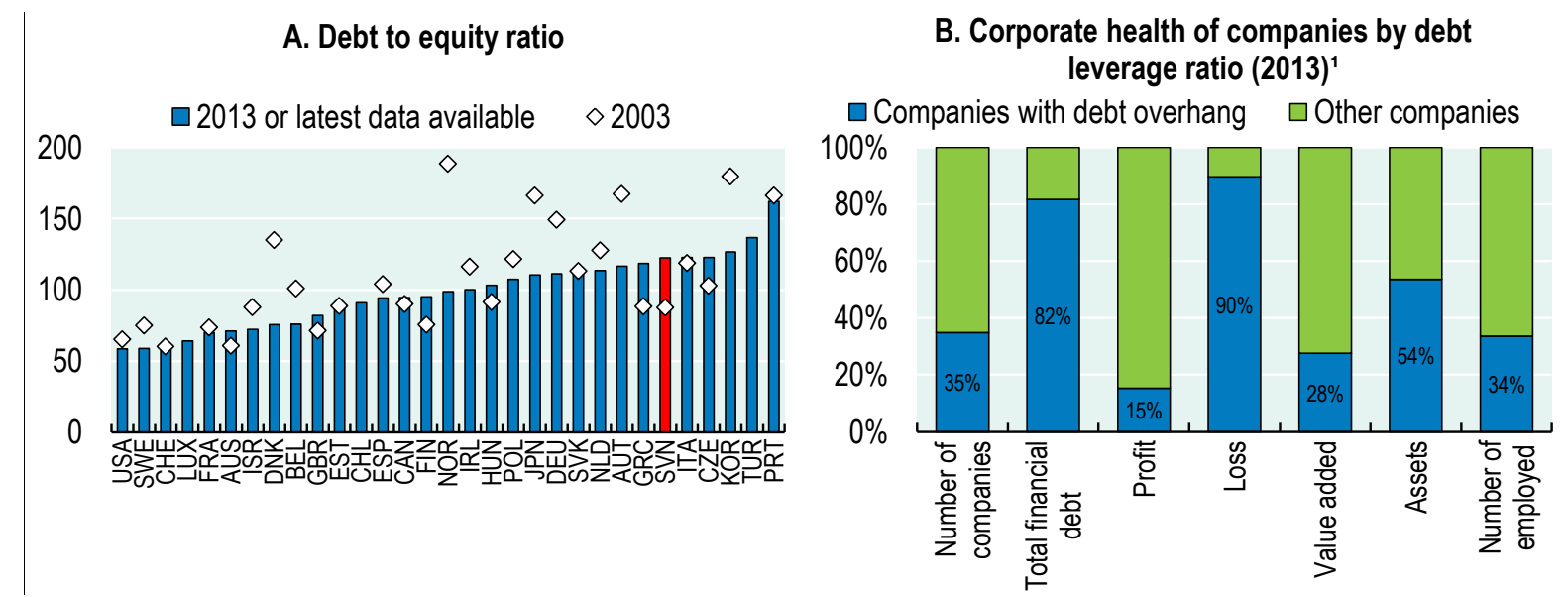

1. Companies with debt overhang are those with negative EBIDTA (earnings before interest, tax, depreciation and amortisation) and those with debt leverage ratio (financial debt over EBITDA) larger than 5.

Source: OECD, Financial indicators database, for Panel A; and Calculations by IMAD, based on raw micro level data (firm-by-firm) from AJPES, for Panel B. 
Figure 4 Deleveraging has been under way, while corporates still face elevated funding costs
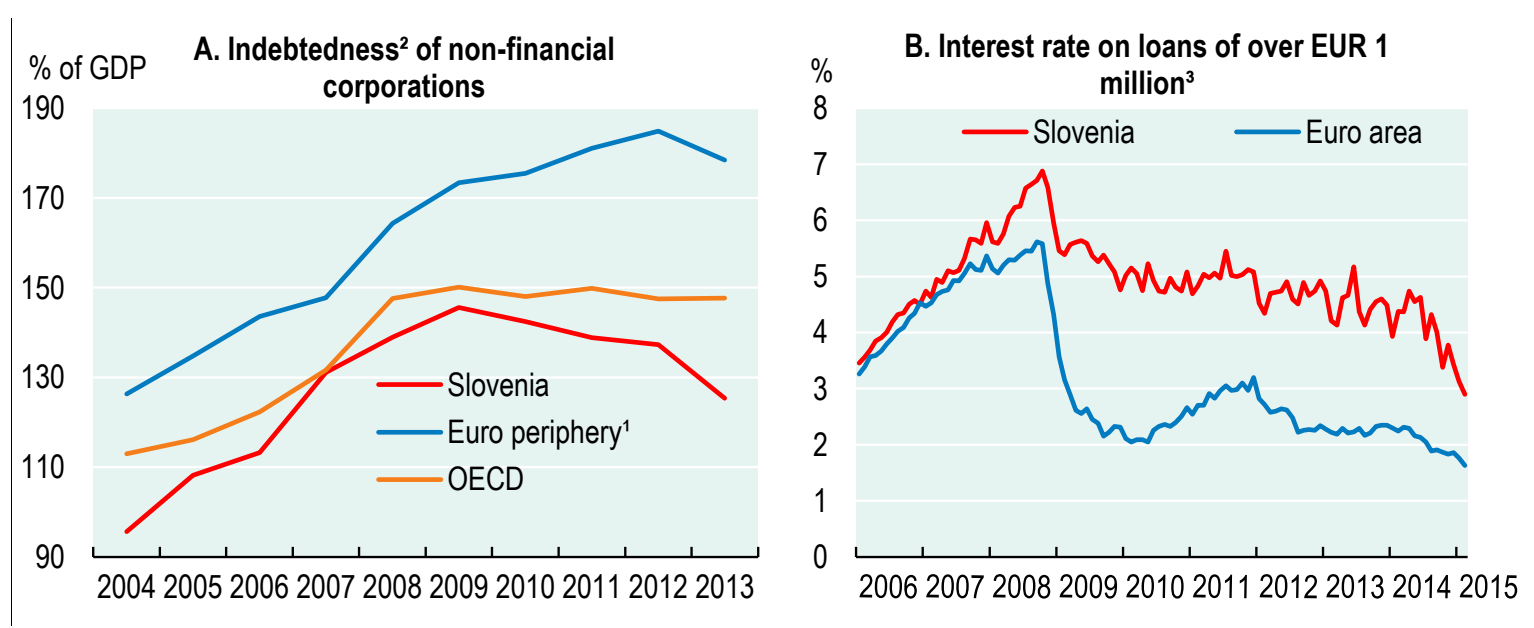

1. The euro periphery is composed of Greece, Portugal, Spain and Ireland.

2. Debt is defined as all liabilities that require payment or payments of interest or principal by the debtor to the creditor at a date or dates in the future. It comprises of all debt instruments except for shares, equity and financial derivatives.

3. Interest rate on loans to non-financial corporations of amount over 1 million euros.

Source: OECD Financial Indicators database, for Panel A; and ECB Statistical Data Warehouse, for Panel B.

\section{Protracted insolvency procedures}

24. Resolving insolvency in Slovenia is very time consuming and recovery rates are low. At a time when Slovenia faces a large burden of non-performing loans and an overleveraged corporate sector, this is especially harmful. According to the Doing Business Survey (World Bank, 2015), it takes on average 2 years to complete a standard bankruptcy procedure (involving a main secured creditor and several unsecured ones). As mentioned in the 2013 Economic Survey the duration is much longer - three or more years - for large complex businesses with numerous creditors. The duration of insolvency procedures is crucial because recovery rate decreases with time. While in Slovenia investors can recover only about 50\% of assets, best practices show that it is possible to achieve recovery rates above 90\% (Finland, Japan and Norway). Such high rates are achieved by rapid bankruptcy procedures that last 5 to 11 months. Hence, decreasing the duration of the insolvency procedures should be the priority of the bankruptcy framework.

25. In Slovenia insolvency procedures are often initiated too late, usually when it is already impossible to save the enterprise. According to Slovenian law, a company that is balance sheet insolvent (value of assets is smaller than the sum of liabilities) can challenge its creditor in court if it demonstrates that it can still meet its obligations. Therefore, insolvent companies that succeed in refinancing their loans can stay insolvent for prolonged periods of time before applying for bankruptcy. Although the law obliges insolvent firms to apply for bankruptcy and sets sanctions for violations, in practice there were no sanctions against such fraudulent behaviour (OECD, 2013a).

\section{Improved insolvency procedures can facilitate credit activity and entrepreneurship}

26. Public policies and programmes related to insolvency procedures can create a business environment that helps entrepreneurs save viable businesses and create more companies and employment. It is important that entrepreneurs are not discouraged from starting a company due to fear of bankruptcy and failure, even if their last attempt failed. Research shows that businesses set up by re-starters grow faster than businesses set up by first timers in terms of turnover and jobs created (European Commission, 2011). 
27. In Slovenia there is stigma of failure. In surveys, when presented with the statement "Entrepreneurs who failed should have a second chance", 32\% of respondents disagree with the statement, the highest percentage among the 33 countries and twice the average (OECD, 2013b). Perhaps this is because the public perceives that bankruptcies are associated with fraud. The government should therefore actively pursue policies to reduce stigma of failure and create an environment that does not discourage fresh start of failed non-fraudulent entrepreneurs. The systematic recognition of honest vs. dishonest entrepreneurs is essential. In the UK for example, dishonest entrepreneurs are identified by the behaviour prior to or during the bankruptcy process (reckless expenditure of credit, paying family members, "evaporation" of assets, etc.) and are then liable for prosecution (European Commission, 2011).

28. Effective systems for secured and unsecured creditors to protect their rights are important also to facilitate credit activity. Slovenia scores low on the "getting credit" component of the Doing Business Survey (World Bank, 2015). It is at the bottom of the high-income OECD country group on the strength of legal rights, which measures the degree to which collateral and bankruptcy laws facilitate lending. According to the Global Competitiveness indicators (World Economic Forum, 2014), access to financing is identified as the most problematic factor for doing business in the country. On the ease of access to loans Slovenia is one of the worst performing countries, ranking 140 out of 144 . Certainly, such a low score is a consequence of plethora of reasons: the high corporate leverage, the unhealthy balance sheets of banks and the prolonged crisis. Nevertheless, further improvements in insolvency procedures would be one important step in resolving the credit crunch environment.

29. In 2013 the parliament passed important reforms to facilitate early restructuring of viable companies. The new framework provides for preventive restructuring of viable large and medium-sized companies that could become insolvent within a year. The new framework gives more powers to creditors. Creditors holding at least $20 \%$ of financial claims may demand court-mandated debt restructuring and creditors' restructuring plan has precedence over a potential rival plan by the debtor. Furthermore, smaller creditors now enjoy better protection. An absolute priority rule has been introduced to ensure that if equity is zero, debtor equity will be eliminated, preventing existing owners from blocking the restructuring process. The amendment also improved corporate restructuring features, such as debt-for-equity swaps and corporate spin-offs, to facilitate viable firms continuing as a going concern (IMF, 2014). The overall procedure of court-mandated debt restructuring has been simplified by broadening the scope of companies eligible for a "simplified procedure", which besides micro companies now applies also to small companies. To speed up liquidation of companies after a bankruptcy, auction-style asset sale has been improved.

30. The amendment significantly improves the corporate insolvency regime and, if properly implemented, can facilitate the rehabilitation of viable firms. During 2013-14, about 30 compulsory settlements were completed per year, simplified compulsory settlements increased from 10 in 2013 to 90 in 2014. Furthermore, in 2014, 8 pre-insolvency restructuring proceedings were concluded for the first time. Nevertheless, corporate bankruptcy procedures remain widespread, amounting to close to 1000 per year in 2013-14, twice as many as in 2012 (IMF, 2015a). The effectiveness of the reform should be closely monitored and evaluated based on appropriate indicators at aggregate level, such as recovery rates in all types of insolvency procedures (European Commission, 2014c; IMF, 2014). Indeed, Slovenia has already started evaluating the reform (European Commission, 2015). Institutional capacity could also be improved further to promote successful implementation. The number of judges specialised in commercial law is low. The number of insolvency administrators is insufficient and many lack relevant knowledge in the areas of accounting and finance. Furthermore, there is lack of meaningful cooperation between judges and insolvency administrators (IMF, 2015a and 2015b). 
31. Slovenia could achieve speedy and cost effective debt settlement also via better use of voluntary out-of-court restructuring. In view of overburdened courts and their limited capacity, promoting voluntary out-of-court restructuring is a good alternative. 2013 Economic Survey of Slovenia reports that although allowed under the Slovenian insolvency law, out-of-court restructuring is not explicitly regulated and average time of such restructuring is high in international comparison. Because the process of out-of-court financial restructuring is not legally defined, the Slovenian Banking Association in cooperation with the Bank of Slovenia and the Ministry of Finance drafted the "Slovenian principles of the financial restructuring of corporate debt". As has been recently done in Spain and Portugal for SMEs, additional incentives could be introduced to promote the use of out-of-court restructuring. Debt hair-cuts should be permitted for such procedures and tax and social security should be equalised with other liabilities. A public mediator agency with electronic platform can facilitate mediation by reducing paperwork bureaucracy.

\section{Improving the judiciary}

32. The judiciary has been slow to deal with cases despite recent improvements in procedures. Slovenia has made progress in accountability of judges and efficiency of the judicial system. In 2008, the Supreme Court established a computerised case management system (Judicial Data Warehouse), which has improved the management of human resources between courts, speeding up litigation and reducing the backlog (OECD, 2013a). European Commission (2014a) assesses, however, that despite the improvements in the functioning of the court system the length of trials remains long. The backlog of enforcement cases is also still high in comparative terms. In 2012, there were 8.3 pending enforcement cases per 100 inhabitants in Slovenia compared to the EU median of 0.3. Given the difficult economic situation, insolvency cases have risen in numbers. Consequently, in bankruptcy cases against legal entities the clearance rate fell from $83 \%$ in 2012 to $67 \%$ in 2013, leading to a $32 \%$ increase in the number of pending cases. Nevertheless, the proportion of insolvency proceedings involving legal entities resolved within nine months of filing improved from 57\% in 2009 to 63\% in 2013 (European Commission, 2014a).

33. Independence of the judiciary could be improved. According to the Global Competitiveness Indicators (World Economic Forum, 2014), the Slovenian judiciary ranks low on perceived judicial independence from government, citizens, or firms. Among OECD countries, only Mexico, Spain, Turkey and Slovak Republic rank lower. The 2014 EU Justice Scoreboard reports that among the EU countries Slovenia has the highest number of judges per capita and one of the highest general government expenditures on law courts as percentage of GDP. While low perception of the judicial system may partly be a consequence of open attacks on some decisions by judges in the recent past, the perception had been low even before. It is the responsibility of all branches of government to ensure respect of the judiciary. Obviously, the foremost responsibility rests with the judicial branch itself that needs to improve quality, independence and efficiency of the justice system. 


\section{Recommendations on restoring the financial sector and corporate deleveraging}

\section{Key recommendations}

- Enhance the leading role of the Bank Asset Management Company to ensure swift restructuring of companies and effective liquidation of assets.

- $\quad$ For the most important firms to be restructured, ensure that all assets in a company group are transferred to the Bank Asset Management Company.

- Bank Asset Management Company should maintain its independence and ability to attract highly professional staff, while adhering to the highest standards of corporate governance and transparency.

- Monitor the implementation of the new insolvency regulation and improve institutional capacity by training judges and insolvency administrators. Make out-of-court restructuring faster and more attractive.

\section{Other recommendations}

- $\quad$ Privatise state-owned banks without retaining blocking minority shareholdings.

- In the context of the single supervisory mechanism framework, the bank supervisor should more closely monitor banks' adherence to regulations and guidance, and encourage banks to improve their risk management.

- Enhance corporate deleveraging by raising equity through privatisation and attracting foreign investors, thus strengthening also corporate governance.

- $\quad$ Set up a system for systematic recognition of honest vs. dishonest entrepreneurs during bankruptcy. Actively pursue policies to reduce stigma of failure and create an environment that encourages fresh start.

- Improve quality, independence and efficiency of the justice system. All branches of government should ensure respect of the judiciary. 


\section{BIBLIOGRAPHY}

BAMC (2014), Annual Report 2013, Bank Assets Management Company.

Bank of Slovenia (2014a), Policy Strategy Paper for Slovenia, Ljubljana, 17 July 2014.

Bank of Slovenia (2014b), Financial Stability Review, May 2014.

Bank of Slovenia (2013), Report on comprehensive review of the banking system and associated measures. Press Release, 12 December 2013.

CPC (2013), State of Corruption in Slovenia, 2013, Commission for the Prevention of Corruption (in Slovenian), https://www.kpk-rs.si/upload/t_datoteke/Ocena_stanja_korupcije_v_RS.pdf

Damijan, J.P. (2014), "Corporate financial soundness and its impact on firm performance: Implications for corporate debt restructuring in Slovenia", European Bank for Reconstruction and Development, Working paper No. 168.

ECB (2014), Aggregate report on the comprehensive assessment, October 2014.

European Commission (2015), Commission staff working document: Country Report Slovenia 2015. Brussels, 26.5.2015.

European Commission (2014a), Slovenia: Review of progress on policy measures relevant for the correction of macroeconomic imbalances, November 2014.

European Commission (2014b), Macroeconomic Imbalances, Slovenia 2014. Occasional Papers 187, March 2014.

European Commission (2014c), Commission staff working document: Assessment of the 2014 national reform programme and stability programme for Slovenia.

European Commission (2013), State aid: Commission approves rescue or restructuring aid for five Slovenian banks. Press release, Brussels, 18 December 2013.

European Commission (2011), A Second Chance for Entrepreneurs: Prevention of Bankruptcy, Simplification of Bankruptcy Procedures and Support for a Fresh Start, Final Report of the Expert Group, Enterprise and Industry Directorate-General, European Commission.

IMAD (2014a), Autumn forecast of economic trends 2014.

IMAD (2014b), Indebtedness and deleveraging of Slovenian firms, Economic Issues 2014.

IMF (2015a), Republic of Slovenia: 2014 Article IV consultation, IMF Country Report No. 15/41, February 2015. 
IMF (2014), Republic of Slovenia: 2013 Article IV consultation, IMF Country Report No. 14/11.

Klingebiel, D. (2000) "The Use of Asset Management Companies in the Resolution of Banking Crises", World Bank Policy Research Working Papers, No. 2284, World Bank.

Laeven, L. and Valencia, F. (2008), Systemic banking crises: A new database. IMF Working Paper No. $08 / 224$

OECD (2013a), OECD Economic Surveys: Slovenia 2013, OECD Publishing, Paris.

DOI: http://dx.doi.org/10.1787/eco_surveys-svn-2013-en

OECD (2013b), Entrepreneurship at a Glance 2013, OECD Publishing, Paris.

DOI: http://dx.doi.org/10.1787/entrepreneur_aag-2013-en

Woo, D. (2000), Two Approaches to Resolving Nonperforming Assets During Financial Crises, IMF Working Paper No. 00/33.

World Bank (2015), Doing Business Survey 2015.

World Economic forum (2014), Global Competitiveness Report 2014 - 2015. 


\section{WORKING PAPERS}

The full series of Economics Department Working Papers can be consulted at www.oecd.org/eco/workingpapers

1242. The economic consequences of an ageing population in Slovenia (June 2015) by Peter Walkenhorst and Urban Sila

1241. Raising competitiveness and long-term growth of the Slovenian economy (June 2015) by Urban Sila, Nataša Jemec and Hermes Morgavi

1240. Frontier firms, technology diffusion and public policy: micro evidence from OECD countries (June 2015) by Dan Andrews, Chiara Criscuolo and Peter N. Gal.

1239. Luxembourg - addressing new challenges in a major financial sector (June 2015) by Eckhard Wurzel and Damien Azzopardi

1238. Spillovers from the global productivity frontier and public policy: industry level evidence (June 2015) by Alessandro Saia, Dan Andrews and Silvia Albrizio

1237. The stabilisation properties of immovable property taxation: evidence from OECD countries (May 2015) by Hansjörg Blöchliger, Balázs Égert, Bastien Alvarez and Aleksandra Paciorek

1236. Making the most of natural resources in Indonesia

(May 2015) by Richard Dutu

1235. Reforming the pension system to increase coverage and equity in Colombia.

(May 2015) by Christine de la Maisonneuve

1234. Making Colombia's tax policy more efficient, fair and green

(May 2015) by Christian Daude, Sarah Perret and Bert Brys

1233. Skills and labour market performance in Sweden

(May 2015) by Margherita Bussi and Jon Kristian Pareliussen

1232. Skills and inclusive growth in Sweden

(May 2015) by Jon Kristian Pareliussen, Margherita Bussi, Christophe André and Vincent Koen

1231. Incorporating anchored inflation expectations in the Phillips Curve and in the derivation of OECD measures of equilibrium unemployment

(May 2015) by Elena Rusticelli, David Turner and Maria Chiara Cavalleri

1230. Macroeconomic uncertainties, prudent debt targets and fiscal rules,

(July 2015) by Falilou Fall and Jean-Marc Fournier

1229. Limits to government debt sustainability

(July 2015) by Jean-Marc Fournier and Falilou Fall

1228. Government debt indicators: understanding the data

(July 2015) by Debbie Bloch and Falilou Fall 
1227. The costs of flexibility-enhancing structural reforms: a literature review

(July 2015) by Tito Boeri, Pierre Cahuc and André Zylberberg

1226. Household finance and income inequality in the euro area

(June 2015) by Oliver Denk and Alexandre Cazenave-Lacroutz

1225. Financial sector pay and labour income inequality: evidence from Europe (June 2015) by Oliver Denk

1224. Finance and income inequality in OECD countries (June 2015) by Oliver Denk and Boris Cournède

1223. Finance and economic growth in OECD and G20 countries (June 2015) by Boris Cournède and Oliver Denk

1222. What impedes household investment in energy efficiency and renewable energy?

(May 2015) by Nadia Ameli and Nicola Brandt

1221. Recent trends in productivity in China - shift-share analysis of labour productivity growth and the evolution of the productivity gap

(May 2015) by Margit Molnar and Thomas Chalaux

1220. Assessing China's skills gap and inequalities in education

(May 2015) by Margit Molnar, Boqing Wang and Ruidong Gao

1219. Providing the right skills to all in China - from "made in China" to "created in China"

(May 2015) by Margit Molnar and Vincent Koen

1218. Agricultural reforms and bridging the gap for rural China

(May 2015) by Ben Westmore

1217. A snapshot of China's service sector

(May 2015) by Margit Molnar and Wei Wang

1216. Does the post-crisis weakness of global trade solely reflect weak demand?

(May 2015) by Patrice Ollivaud and Cyrille Schwellnus

1215. Estonia: raising productivity and benefitting more from openness

(May 2015) by Andreas Kappeler

1214. Estonia: making the most of human capital

(May 2015) by Andrés Fuentes Hutfilter

1213. The Czech labour market: documenting structural change and remaining challenges (May 2015) by Sónia Araújo and Petr Malecek

1212. Reforming the Slovak public sector

(April 2015) by Lilas Demmou and Robert Price

1211. Spurring growth in lagging regions in the Slovak Republic

(April 2015) by Lilas Demmou, Gabriel Machlica, Martin Haluš and Robert Menkyna 